\title{
ETNOGRAFI DALAM PEMBELAJARAN BAHASA INGGRIS
}

\author{
Praptika Dwi Febrianti \\ Universitas Muhammadiyah Purwokerto \\ tikafebrianti2393@,gmail.com
}

\begin{abstract}
Abstrak: Makalah ini mengungkapkan tentang sebuah metode penelitian Etnografi. Etnografer menggambarkan dan menginterpretasikan perilaku, kebiasaan, bahasa, dan lainlain yang dipelajari dan dianut oleh suatu kelompok budaya. Latar belakang makalah ini berhubungan dengan pembelajaran bahasa, dimana bahasa adalah suatu produk kebudayaan yang memiliki fenomena atau karakteristik pada kehidupan masyarakat. Bahasa Inggris sebagai bahasa asing memiliki karakteristik yang berbeda dengan Bahasa Indonesia, sehingga menimbulkan berbagai reaksi bagi masyarakat Indonesia dalam proses pembelajaran. Jenis utama yang sering muncul dalam laporan-laporan penelitian pendidikan adalah etnografi realis, studi kasus, dan etnografi kritis. Tujuan etnografi adalah mendeskripsikan sistem kebudayaan dari sudut pandang penduduk atau penutur asli. Menurut Spradley (1980) ada enam langkah dalam penelitian etnografi yaitu pemilihan proyek etnografi, pengajuan pertanyaan, pengumpulan data (observasi, wawancara, dokumentasi), perekaman data, analisis data, dan penulisan laporan.
\end{abstract}

Kata kunci: Etnografi, kebudayaan, bahasa, fenomena, karakteristik

\section{PENDAHULUAN}

Manusia diciptakan sebagai makhluk sosial yang tidak pernah terlepas dari manusia yang lainnya. Hal tersebut menyebabkan terjadinya proses interaksi dan komunikasi untuk menyampaikan pikiran, gagasan, konsep, atau perasaan. Bahasa merupakan salah satu alat yang digunakan untuk berkomunikasi dalam masyarakat. Kelangsungan hidup sebuah bahasa dipengaruhi oleh dinamika yang terjadi pada setiap penutur dan berkaitan dengan hal-hal yang dialami penuturnya. Seiring berkembangnya waktu, bahasa yang digunakan pun semakin berkembang mengikuti pola pikir manusianya. Di dunia ini, keanekaragaman bahasa tidak dapat dipisahkan dari keanekaragaman budaya. Dari adanya multilingual atau keanekaragaman bahasa itu sendiri dapat menimbulkan permasalahan atau fenomena dalam berkomunikasi.

Sebagai produk budaya, bahasa dapat menjadi objek bagi kajian etnografi. Menurut Hanifah (2010), etnografi merupakan cabang antropologi yang digunakan untuk menggambarkan, menjelaskan, dan menganalisis unsur kebudayaan suatu masyarakat atau suku bangsa. Etnografi mengungkap uraian terperinci mengenai aspek cara berperilaku dan 
cara berpikir manusia yang dituangkan dalam bentuk tulisan, foto, gambar, atau film. Kebudayaan meliputi sesuatu yang berhubungan dengan perilaku, pemikiran dan keyakinan suatu masyarakat. Menurut Spradley (1980:6-8) yang dikutip oleh Hanifah (2010), kebudayaan merupakan seluruh pengetahuan yang dipelajari manusia dan digunakan untuk mengintrepretasikan pengalaman dan membentuk tingkah laku, dan etnografi merupakan penelitian yang membahas kebudayaan, baik eksplisit maupun implisit.

Wijaya (2018) mengatakan bahwa etnografi digunakan untuk penelitian di banyak bidang seperti kedokteran, psikologi, sosiologi, sistem informasi, pendidikan dan lainnya. Kajian ini fokus terhadap lingkungan sekitar sistem budaya seperti masyarakat, kelompok, sistem, organisasi, dan semacamnya.

Secara bahasa, etnografi merupakan potret suatu masyarakat. Menurut Harris dan Johnson dalam Hanifah (2010), penelitian etnografi adalah gambaran tertulis tentang suatu budaya, yaitu adat, kepercayaan, dan perilaku berdasarkan pengamatan peneliti yang terjun langsung ke lapangan. Dimana seorang peneliti harus berada di antara objek yang akan diteliti untuk dapat menghasilkan sumber data yang natural.

Bahasa merupakan produk budaya dapat mencerminkan karakteristik dari suatu masyarakat tertentu. Bagi masyarakat Indonesia, bahasa Inggris merupakan bahasa asing yang dipelajari disekolah maupun universitas. Menurut Suwartono (2010), pembelajaran bahasa asing di dalam setting pendidikan formal atau nonformal yang diselenggarakan di dalam kelas memiliki kelebihan dibandingkan yang dilakukan di luar kelas, di antaranya keterprograman, ketersediaan narasumber (guru), serta mitra berlatih. Namun, pembelajaran di dalam kelas ini bukan merupakan satu-satunya alam pembelajaran yang dapat memberikan jaminan keberhasilan dalam belajar bahasa, apalagi bahasa asing. Faktor utama keberhasilan dalam belajar bahasa adalah guru. Fungsi guru sebagai sebagai fasilitator, inspirator, motivator, dan direktor pembelajaran memainkan peranan sentral dalam mempersiapkan pemelajar yang otonom. Apabila diselenggarakan dengan baik dan benar, pendidikan bahasa asing di kelas-kelas dapat memberikan kontribusi terhadap keberhasilan menguasai bahasa asing. Penelitian etnografi dalam dunia pendidikan dapat dilakukan untuk memahami pola hubungan antar guru disebuah sekolah, proses pengajaran dengan menggunakan metode atau media tertentu (seperti pengajaran kosa kata dengan metode Total Physical Response), atau prosedur pelaksanaan kegiatan tertentu, seperti program 
English Speaking Days di suatu sekolah dan pembelajaran merancang melalui internet di sebuah kelas (Hanifah, 2010).

Banyak hal yang dapat dikaji dengan menggunakan pendekatan Etnografi untuk memahami suatu peristiwa, fenomena, atau kejadian khususnya dalam pembelajaran Bahasa Inggris yang dianggap sebagai bahasa Internasional, dimana Bahasa Inggris merupakan bahasa asing bagi masyarakat Indonesia yang memiliki dampak tersendiri bagi para pembelajarnya. Kesulitan, kemudahan, pengaruh, bahkan motivasi belajar pun terjadi dalam pembelajaran bahasa asing bagi siswa maupun gurunya sendiri. Suwartono (2016) mengatakan bahwa, "Creativity in ELT can find itself expressed with regards to methodology, media, resources, material, classroom activities, or in some combination these." Pada dasarnya, setiap guru memiliki kreativitas yang berbeda dalam pelaksanaan pembelajaran bahasa asing baik dari segi metode, media, buku sumber, aktivitas, dan lainlain. Fenomena dari suatu kelompok yang menggunakan karakteristik tertentu dapat diangkat dalam sebuah penelitian yang menggunakan pendekatan etnografi dengan tujuan untuk mengungkapkan realita yang terjadi dalam dunia pendidikan saat ini.

Dalam makalah ini akan membahas (1) Apa Etnografi itu?, (2) Apa jenis-jenis penelitian Etnografi?, (3) Apa tujuan penelitian Etnografi?, dan (4) Bagaimana prosedur penelitian Etnografi?

\section{PEMBAHASAN}

\section{Hakikat Etnografi}

Istilah Etnography berasal dari bahasa Yunani, kata ethos yang berarti "orang" dan graphein yang berarti "tulisan". Istilah itu diartikan sebagai sejenis tulisan yang menggunakan bahan-bahan dari penelitian lapangan untuk menggambarkan kebudayaan manusia (Hanifah, 2010). Naibaho, dkk (2015) mengatakan bahwa Etnografi berasal dari kata ethno (bangsa) dan grafhy (menguraikan). Etnografi pada dasarnya merupakan kegiatan penelitian untuk memahami cara orang-orang berinteraksi dan bekerjasama melalui fenomena dalam kehidupan sehari-hari. Salah satu tujuannya adalah menguraikan suatu budaya secara menyeluruh dari semua aspek yang bersifat material (seperti artefak budaya) dan abstrak (seperti pengalaman, kepercayaan, norma, dan system nilai kelompok yang diteliti). 
Menurut Duranti dalam Hanifah (2010), Etnografi adalah deskripsi tertulis mengenai organisasi sosial, aktivitas sosial, symbol dan sumber material dan karakteristik praktik interpretasi suatu kelompok manusia tertentu. Penelitian etnografi merupakan penelitian mengenai aktivitas sosial dan perilaku kelompok masyarakat tertentu. Deskripsi itu diperoleh oleh peneliti dengan cara berpartisipasi secara langsung dan lama terhadap kehidupan social suatu masyarakat.

Menurut Creswell (2003), etnografi adalah suatu desain kualitatif dimana seorang peneliti menggambarkan dan menginterpretasikan pola nilai, perilaku, kepercayaan, dan bahasa yang dipelajari dan dianut oleh suatu kelompok budaya. Etnografi berfokus pada keseluruhan kelompok. Seorang etnografer, dapat meneliti suatu pola yang diikuti satu kelompok misalnya oleh sejumlah lebih dari 20 orang. Suwartono (2014:121-122) mengatakan bahwa studi etnografi biasanya meneliti sekelompok masyarakat dengan fokus pada kultur yang berlangsung disana. Penelitian dilakukan harus berurusan dengan antropologi, budaya, etnik, ras, dan sejenisnya. Aktivitas sehari-hari yang berlangsung di kelas, sekolah, atau pondok pesantren pun bisa menjadi objek kajian etnografi. Dengan demikian, studi etnografi membidik pikiran dan pola-pola perilaku manusia yang sebagian dapat diamati melalui kegiatan hidupnya.

Etnografi adalah studi tentang bagaimana partisipan berpartisipasi dalam praktik social setiap hari (Dervin and Dyer, 2016:239 dalam Wijaya 2018). Etnografi merupakan metode penelitian kualitatif yang didasarkan pada pengamatan langsung. Naibaho, dkk (2015) menambahkan, etnografi melibatkan pengamatan yang cukup panjang terhadap suatu kelompok, sehingga peneliti memahami betul bagaimana kehidupan keseharian subjek penelitian yang dipertajam dengan adanya indepth interview terhadap masing-masing individu dalam kelompok tersebut. Suwartono (2014:48-49) mengatakan bahwa wawancara memungkinkan seorang peneliti menyusup ke "alam" pikiran orang lain, tepatnya hal-hal yang berhubungan dengan perasaan, pikiran, pengalaman, pendapat, dan lainnya yang tidak bisa diamati. Keuntungan menggunakan wawancara ini adalah wawancara bisa lebih spontan dalam pembicaraan, lebih kecil terhalangi mengalirnya informasi, dan lebih besar peluang bisa menjajaki berbagai aspek permasalahan yang tidak terbatas. Penelitian etnografi khusus menggunakan tiga macam metode pengumpulan data yaitu wawancara, 
observasi, dan dokumen; serta menghasilkan tiga jenis data, yaitu kutipan, uraian, dan kutipan dokumen yang tergabung dalam satu produk yaitu uraian naratif.

Menurut Naibaho, dkk (2015), penelitian etnografi memiliki ciri khas yaitu penelitian bersifat holistik, integrative, thick description dan menggunakan analisis kualitatif dalam mencari sudut pandang yang semula (native's point of view). Teknik pengumpulan data dilakukan dengan menggunakan observasi-partisipasi dan wawancara secara terbuka dan mendalam, sehingga penelitian etnografi memerlukan waktu yang lama. Suharyadi (2014) dalam artikelnya menambahkan bahwa etnografer melihat dan mendengar kemudian membuat kesimpulan tentang hal yang diketahui orang. Kesimpulan itu dibuat berdasarkan tiga sumber, yaitu dari apa yang dikatakan orang, dari cara orang yang bertindak, dan dari berbagai artefak yang digunakan orang.

Dari pendapat beberapa ahli diatas, dapat disimpulkan bahwa Etnografi merupakan salah satu metode penelitian kualitatif dengan tujuan mendeskripsikan karakteristik suatu individu maupun kelompok secara mendalam. Deskripsi etnografi tersebut merupakan pengetahuan mengenai sistem budaya dalam suatu masyarakat.

\section{Jenis-Jenis Etnografi}

Menurut Creswell (2008:475) dalam Hanifah (2010), penelitian etnografi memiliki beragam bentuk. Namun, jenis utama yang sering muncul dalam laporan-laporan penelitian pendidikan adalah etnografi realis, studi kasus, dan etnografi kritis.

Pertama, etnografi realis merupakan pendekatan yang menggambarkan situasi budaya para partisipan secara obyektif berdasarkan informasi yang diperoleh langsung dari para partisipan di lapangan penelitian dan dipaparkan dengan menggunakan sudut pandang orang ketiga (third person point of view). Ada tiga ciri khas etnografi realis menurut Creswell (2008:475), yaitu peneliti sebagai peliput fakta hanya mengungkapkan laporan penelitiannya melalui pandang orang ketiga berdasarkan data yang diperolei melalui pengamatan atas partisipan dan pandangan-pandangan mereka, peneliti memaparkan data-data obyektif dalam bentuk informasi yang terukur dan bebas serta mengikutsertakan data-data tentang kehidupan sehari-hari para partisipan yang disusun dalam kategori-kategori standar penggambaran kultural, dan peneliti mengungkapkan pandangan para partisipan melalui 
kutipan-kutipan penuturan mereka yang diedit tanpa merubah makna tentang gambaran budaya yang diteliti pada bagian akhir laporan.

Kedua, studi kasus sebagai sebuah bentuk etnografi didefinisikan sebagai "an in-depth exploration of a bounded system (e.g. an activity, event, process, or individuals) based on extensive collection" (Creswell, 2008:476). Istilah "bounded" atau "terbatas" dalam definisi ini berarti bahwa 'kasus' yang diteliti terpisah dari hal-hal lain dalam dimensi waktu, tempat, dan batas-batas fisik tertentu. Artinya, hasil penelitian yang diperoleh hanya berlaku bagi objek yang diteliti dan tidak dapat digeneralisasi pada objek lain meskipun masih sejenis. Kebanyakan karya dan teori Freud dikembangkan berdasarkan berbagai studi kasus terhadap individu yang dilakukan dengan menganalisis setiap aspek dan pengalaman hidup seseorang untuk menemukan pola-pola dan penyebab tingkah laku orang tersebut. Objek yang biasanya diteliti dengan prosedur ini memiliki karakteristik; kasus bisa berbentuk individu tunggal, beberapa individu yang terpisah dalam sebuah kelompok khusus, sebuah program, peristiwa-peristiwa yang berhubungan erat, atau aktivitas-aktivitas. Jadi, dalam konteks pendidikan kasus yang diteliti bisa berbentuk "Intervensi Bahasa Ibu dalam Pelafalan Bahasa Inggris oleh Siswa-Siswa Berkebangsaan Jepang di Sekolah Internasional Global Jakarta", "Upaya-Upaya Kelompok Dosen Bahasa Inggris di Universitas X Meningkatkan Kualitas Pembelajaran Bahasa Inggris Mahasiswa", "Proses Penulisan Buku Ajar Reading Comprehension di Program Studi Pendidikan Bahasa Inggris Universitas X", dan lain-lain.

Ketiga, etnografi kritis merupakan pendekatan penelitian yang digunakan untuk membantu dan memberdayakan kelompok-kelompok masyarakat yang termarjinalisasi. Etnografer kritis biasanya merupakan individu berpikiran politis yang melalui penelitiannya ingin memberikan bantuan melawan ketidakadilan dan penindasan. Menurut Creswell (2008:478) ciri khas etnografi kritis adalah etnografer kritis mempelajari isu-isu sosial (kekuasaan, pemberdayaan, ketidakadilan, dominasi, represi, hegemony, dan penindasan), penelitian diarahkan urtuk menghentikan marginalisasi terhadap individu-individu yang diteliti (dengan cara bekerjasama, berpartisipasi aktif, menegosiasikan laporan akhir dengan para partisipan, dan memberikan bantuan atau perhatian ketika memasuki dan meninggalkan lapangan penelitian), etnografer kritis menyadari bahwa interpretasinya dipengaruhi deh kebudayaannya sendiri, etnografer kritis menempatkan dirinya sebagai pemberdaya para partisipan (laporan penelitiannya memuat orientasi pada nilai-nilai, pemberdayaan partisipan 
melalui peningkatan otoritas, dan tantangan kepada status-quo), posisi etnografer kritis yang tidak netral memungkinkan baginya untuk menyarankan perubahan dalam masyarakat agar kelompok-kelompok yang seama ini terpinggirkan tidak lagi dimarginalkan, laporan penelitian memuat data yang variati dan kontradiktif yang diperoleh dengan beragan metode.

\section{Tujuan Etnografi}

Menurut Spradley dalam Suharyadi (2014), tujuan etnografi adalah mendeskripsikan sistem kebudayaan dari sudut pandang penduduk asli. Oleh karena itu, masyarakat yang diteliti adalah objek sekaligus subjek penelitian. Kajian Etnografi juga ditujukan untuk memahami isu yang ada untuk menambah pengetahuan mengenai suatu budaya dengan menciptakan penafsiran terhadap suatu masyarakat tertentu. Dengan kata lain, etnografi bertujuan untuk menggambarkan budaya secara detail, termasuk bahasa, adat istiadat, nilainilai, upacara keagamaan, dan undang-undang.

\section{Prosedur Penelitian Etnografi}

Menurut Hanifah (2010), penelitian etnografi berlangsung dalam bentuk siklus, seperti pengumpulan data, analisis data, dan interpretasi yang dapat dilakukan secara berkelanjutan dan diulang.

Spradley (1980:22-35) dalam Hanifah (2010) mengatakan bahwa siklus penelitian etnografi mencakup enam langkah, yaitu (1) Pemilihan Proyek Etnografi, (2) pengajuan pertanyaan, (3) pengumpulan data, (4) perekaman data, (5) analisis data, dan (6) penulisan laporan.

Pertama, menurut Creswell (2C08:486), langkah-langkah utama pelaksanaan penelitian adalah mengidentifikasi tujuan penelitian, desain apa yang akan digunakan, dan bagaimana tujuan itu dihubungkan dengan masalah penelitian. Langkah tersebut akan menentukan apakah proyek penelitian yang akan dilaksanakan merupakan desain etnografi realis, studi kasus, atau etnografi kritis. Setelah itu, peneliti perlu meminta izin dari otoritas lembaga atau kelompok yang akan diteliti. Hanifah (2010:20-21) menambahkan bahwa seorang informan adalah seorang pembicara asli yang berbicara dengan mengulang katakata, frasa dan kalimat dalam bahasa atau dialeknya sebagai model imitasi dan sumber informasi. Spradley (1997:35) mengungkapkan bahwa informan merupakan pembicara asli 
(native speaker), karena informan memberikan model untuk dicontoh oleh etnografer. Etnografer ingin belajar menggunakan bahasa asli dengan cara yang dilakukan oleh informan. Informan merupakan sumber informasi mengenai apa yang mereka ketahui tentang budaya atau kehidupannya, dan tugas peneliti adalah mendeskripsikan apa yang diketahui informan untuk disampaikan kepada khalayak. Pada dasarnya, hampir semua orang dapat menjadi informan, namun tidak setiap orang dapat menjadi informan yang baik. Salah satu tantangan besar dalam melakukan etnografi adalah untuk memulai, mengembangkan, dam mempertahankan hubungan dengan informan yang produktif (Spradley, 1997:59). Keberhasilan sebuah penelitian etnografi bergantung banyak faktor. Salah satunya adalah informan. Pemilihan seorang informan sangat penting karena ia yang akan diajak bekerja sama untuk mengumpulkan data. Banyak peneliti mula yang tidak berhasil karena kegagalannya dalam menemukan informan yang baik, yaitu seorang yang membantu etnografer dalam mempelajari budaya informan yang pada waktu yang sama juga belajar mengenai keterampilan mewawancarai. Informan yang dipilih harus memenuhi syarat agar menghasilkan data yang baik. Spradley (1997:11) mengemukakan bahwa persyaratan minimal untuk memilih informan yang baik yaitu enkulturasi penuh, keterlibatan langsung, suasana budaya yang tidak dikenal, cukup waktu, dan nonanalitis.

Kedua, pengajuan pertanyaan utama yang diajukan pada saat observasi adalah: "Siapa yang ada di latar penelitian?", "Apa yang mereka lakukan?" dan "Apa latar fisik situasi sosial tersebut?". Setelah itu, peneliti melanjutkan observasinya dengan mengajukan pertanyaan-pertanyaan yang lebih terfokus.

Ketiga, pengumpulan data dilakukan dengan prosedur beragam (multiple procedures), dan intensitas prosedur-prosedur itu bervariasi sesuai tipe etnografi yang dilakukan. Dalam penelitian etnografi realis, peneliti tinggal bersama dengan para partisipan dalam waktu yang relatif lama. Peneliti membuat catatan-catatan lapangan berdasarkan data yang diperoleh dari wawancara, pengamatan langsung terhadap kegiatan-kegiatan kebudayaan para partisipan, dan pengamatan atas artifak, dan simbol-simbol. Dalam penelitian studi kasus, sesuai dengan tujuan untuk memeroleh pemahaman mendalam tentang suatu fenomena atau kasus, peneliti dapat mengumpulkan data melalui wawancara, pengamatan, dokumen, dan rekaman-rekaman audio visual. Sedangkan, dalam penelitian etnografi kritis, pengumpulan data lebih terfokus pada kolaborasi antara peneliti dan partisipan dengan agenda 
meningkatkan pemahaman para partisipan tentang situasi tertentu dalam hidup mereka dan langkah-langkah apa yang perlu diambil untuk memperbaiki situasi itu. Kerjasama ini bisa berbentuk penglihatan partisipan dalam membuat desain penelitian, perumusan pertanyaan pertanyaan penelitian, pengumpulan data, dan analisis data. Bahkan partisipan mungkin saja dilibatkan secara aktif dalam penulisan laporan akhir. Menurut Denzin yang dikutip oleh Mulyana (2003), Pengumpulan data yang sering dilakukan dalam penelitian etnografi yaitu dokumen, wawancara dengan responden dan informan, partisipasi langsung dan introspeksi. Suwartono (2014:14) menambahkan bahwa dalam observasi partisipan, seorang peneliti bisa menjadi anggota suatu kelompok atau organisasi tertentu dan mengamatinya serta menghimpun data. Salah satu kelebihan dari pengamatan jenis ini adalah kemampuan menjaga kealamiahannya.

Keempat, data etnografi yang diperoleh melalui berbagai prosedur tersebut direkam dan diorganisasikan sebaik mungkin sesuai dengan jenis dan bentuknya. Sebagian data dapat direkam dalam bentuk catatan lapangan. Sebagian lagi direkam dalam bentuk foto, peta, video, dan cara-cara lain.

Kelima, analisis data dilakukan secara simultan dengan pengumpulan data, karena salah satu tujuan analisis data adalah untuk menemukan dan merumuskan pertanyaanpertanyaan spesifik yang jawabannya dicari dalam rekaman-rekaman data yang sudah ada atau dalam pengumpulan data berikutnya. Seiring dengan diperolehnya jawaban atas pertanyaan tersebut maka pengembangan deskripsi, analisis tema-tema, dan penginterpretasian makna informasi juga telah berlangsung. Dilihat dari tahapannya, data dianalisis melalui empat bentuk: analisis domain (memperoleh gambaran umum atau pengertian menyeluruh tentang objek penelitan atau situasi sosial), analisis taksonomi (menjabarkan domain-domain yang dipilih menjadi lebih rinci untuk mengetahui struktur internalnya), analisis komponensial mencari ciri spesifik pada setiap struktur internal dengan cara mengontraskan antar elemen), dan analisis tema kultural (mencari hubungan diantara domain dan hubungan keseseluruhan).

Keenam, penulisan laporan disesuaikan dengan tipe penelitian yang dilakukan. Etnografi realis ditulis sebagai laporan yang objektif tentang kelompok sosial yang diteliti. Dalam studi kasus, lebih terfokus pada penggambaran terperinci tentang kasus yang diteliti, bukan pada pengembangan tema kultural. Sedangkan studi kasus lain mungkin saja 
menyeimbangkan laporan pada deskripsi dan tema kasus yang diteliti. Dalam etnografi realis, peneliti biasanya menyimpulkan laporannya dengan mengutarakan isu-isu kritis yang menjadi titik-tolak pelaksanaan penelitian, yang kemudian diikuti oleh saran untuk tindak lanjut dan pemaparan tentang perubahan atau keuntungan yang telah diperoleh peneliti dan para partisipan.

Hanifah (2010:19) menambahkan validasi terhadap peneliti sebagai instrument meliputi validasi terhadap metode penelitian kualitatif, penguasaan wawasan terhadap bidang yang diteliti, kesiapan peneliti untuk memasuki objek penelitian, baik secara akademik maupun logistik. Validasi dilakukan oleh peneliti sendiri melalui evaluasi diri seberapa jauh pemahaman terhadap metode kualitatif, penguasaan teori dan wawasan terhadap bidang yang diteliti, sertai kesiapan dan bekal memasuki lapangan. Dalam penelitian kualitatif, instrumen utamanya adalah peneliti sendiri, namun selanjutnya setelah fokus penelitian menjadi jelas, maka kemungkinan akan dikembangkan instrumen penelitan sederhana, yang diharapkan melengkapi data dan membandingkan dengan data yang telah ditentukan melalui observasi dan wawancara. Peneliti akan terjun di lapangan sendiri, baik pada grand tour question, tahap focused and selection, melakukan pengumpulan data, analisis dan membuat kesimpulan.

\section{Contoh Penelitian Etnografi}

Ada beberapa contoh penelitian etnografi yang dilakukakan oleh peneliti-peneliti sebelumnya. Salah satunya diambil dari penelitian etnografi karya Arif Rahman yang berjudul "Strategi Komunikasi Dalam Pembelajaran Bahasa Inggris (Penelitian Etnografi pada Sekolah Internasional AIScho BSD City)". Tujuan penelitian tersebut untuk mengkaji strategi komunikasi dalam pembelajaran bahasa Inggris oleh siswa pada SMP Internasional AIScho BSD City. Terdapat 27 siswa SMP kelas VII Program Internasional AIScho BSD City Kota Tangerang Selatan sebagai subjek penelitian. Peneliti menggunakan pendekatan kualitatif dengan metode etnografi dan mengumpulkan data melalui pengamatan dengan menggunakan audio recorder, catatan lapangan, dan wawancara tidak formal. Data tersebut dianalisis menggunakan teknik analisis performansi yaitu melakukan analisis berdasarkan tuturan yang terjadi secara alamiah dan kompetensi linguistik. 
Hasil penelitian menunjukan bahwa siswa SMP kelas VII Program Internasional AIScho BSD City Kota Tangerang Selatan menggunakan dua strategi komunikasi yaitu komunikasi verbal dan komunikasi nonverbal. Dari hasil penelitian tersebut menunjukan bahwa siswa menggunakan strategi komunikasi dengan dua karakteristik yaitu untuk dapat mempertahankan jalannya komunikasi, untuk menyatakan maksud tertentu dan untuk menguasai kompetensi bahasa dan menguasai bentuk-bentuk tertentu sebagai kompetensi strategis.

Laporan penelitian yang ditulis oleh Arif Rahman menggambarkan jelas bahwa pada kelompok siswa SMP tersebut menggunakan strategi komunikasi dalam pembelajaran bahasa Inggris. Berdasarkan teori Creswell (2008: 475), dapat disimpulkan bahwa hasil penelitian ini termasuk jenis etnografi studi kasus karena objek yang diteliti memiliki karakteristik adanya sebuah program dalam aktivitas pembelajaran bahasa Inggris di suatu kelompok siswa. Dari contoh hasil penelitian tersebut, Suwartono (2010) menambahkan bahwa banyak cara yang dapat ditempuh untuk mempraktikkan atau berlatih menggunakan bahasa asing, bergantung pada profesionalisme guru (untuk konteks pendidikan formal) dan motivasi serta strategi pemelajar sendiri dalam menggali cara-cara yang dinilai paling mangkus bagi dirinya.

\section{KESIMPULAN}

Etnografi merupakan jenis penelitian yang bersifat kualitatif untuk mendeskripsikan atau menggambarkan suatu karakteristik pada individu atau masyarakat mengenai sosial budaya, bahasa, kebiasaaan, hubungan antar manusia, dan lain-lain. Penelitian ini bersifat mendalam dan peneliti bersingunggan langsung dengan permasalahan yang diteliti. Etnografi menjadi metode untuk menggali makna terhadap suatu realitas. Metode etnografi dapat berhasil apabila tahapan-tahapan penelitian dilakukan dengan baik. Sebagai instrument, peneliti harus mampu dan menguasai hal-hal yang akan diteliti dan memiliki kepekaan terhadap lingkungan tersebut.

Dalam bidang pendidikan bahasa, etnografi dapat digunakan untuk menggambarkan atau mendeskripsikan suatu fenomena dan karakteristik dari suatu kelompok yang sedang mempelajari suatu bahasa asing. 


\section{SARAN}

Setelah membaca makalah tentang penelitian etnografi ini, maka diharapkan para peneliti, guru, maupun mahasiswa yang sedang melakukan penelitian atau menempuh tugas akhir dapat melaksanakan penelitian etnografi dengan sistematis dan baik. Penelitian etnografi diharapkan lebih banyak dikembangkan oleh para peneliti karena kajian ini menarik dan dapat menambah wawasan bagi masyarakat khususnya saat mempelajari suatu budaya atau kebiasaan dari kelompok tertentu.

\section{DAFTAR PUSTAKA}

Creswell, John W. 2008. Educational Research:Planning, Conducting, and Evaluating Quantitative and Qualitative Research. New Jersey: Prentice Hall.

Dervin, Fred, and Caroline Dyer. 2016. Constructing Methodology for Qualitative Research. https://doi.org/10.1057/978-1-137-59943-8.

Denzin, Norman K. The Research Art in Sociology. London: butterworth, 1970.

Duranti, A. 1997. Linguistic Anthropology. California: Cambridge University Press.

Hanifah, Ninip. 2010. Penelitian Etnografi dan Penelitian Grounded Theory. Akademi Bahasa Asing Borobudur Jakarta. file:///D:/KUMPULAN\%20JOURNAL/NinipHanifah B10.pdf. (Diakses pada 13 Agustus 2019)

Mulyana, Deddy. 2013. Metodologi Penelitian Kualitatif. Bandung: PT Remaja Rosdakarya.

Naibaho, dkk. 2015. Penelitian Etnografi. file:///D:/KUMPULAN\%20JOURNAL/Penelitian Etnografi.pdf. (Diakses pada 13 Agustus 2019)

Rahman, Arif. 2015. Startegi Komunikasi Dalam Pembelajaran Bahasa Inggris (Penelitian Etnografi Pada Sekolah Internasional AIScho BSD City). https://www.researchgate.net/publication/319384345 STRATEGI KOMUNIKASI DALAM PEMBELAJARAN BAHASA INGGRIS PENELITIAN ETNOGRAFI PADA SEKOLAH INTERNASIOANAL AIScho BSD City. VL 14 DO - 10.21009/BAHTERA.142.04, halaman 142-155

Spradley, James. 1980. Participant Observation. New York: Holt, Rinehart and Winston.

Spradley, James. 2007. Metode Etnografi. Yogyakarta: PT. Tiara Wacana

Suhariyadi. 2014. Etnografi dalam Penelitian Sastra Lisan. https://www.academia.edu/9587747/ETNOGRAFI_dalam_Penelitian_Sastra_Lisan (Diakses pada 13 Agustus 2019)

Suwartono. 2010. Penggunaan Bahasa Asing dalam Konteks Pendidikan Bahasa di Indonesia. Isu-isu Kritis Kebijakan Pendidikan Era Otonomi Daerah (editor: Emzir dan Chan). Bogor: Penerbit Ghalia Indonesia. 
Suwartono. 2014. Dasar-Dasar Metodologi Penelitian. Yogyakarta: Penerbit Andi.

Suwartono. 2016. Teacher's Creativity in ELT. International Seminar on English Language Teaching (ISELT 2016). Sultan Ageng Tirtayasa University.

Wijaya, Hengki. 20178. Analisis Data Kualitatif Model Spradley (Etnografi).

https://www.researchgate.net/publication/323557072 (Diakses pada 13 Agustus 2019) 